zwięźle, napisane dobrym stylem, ale są to już sprawy w literaturze znane i nie wnoszą nic nowego.

Książka jest jednak zdecydowanie opracowaniem potrzebnym (i być może jeszcze wartościowsza okaże się zapowiadana część II) i być może pobudzi innych twórców do ogłoszenia drukiem - podobnych tematycznie monografii, przypominających potworność totalitarnych systemów: narodowosocjalistycznych Niemiec i socjalistycznego Związku Radzieckiego.

Jacek Goclon (Wrocław)

\title{
Witold Bagieński, „Wywiad cywilny Polski Ludowej w latach 1945-1961", t. I-II, uyd. Instytut Pamięci Narodowej Komisja Ścigania Zbrodni Przeciwko Narodowi Polskiemu, Warszawa 2017, ss. 1336 (t. I: ss. 640, t. II: ss. 696)
}

\begin{abstract}
Wywiad cywilny Polski Ludowej w latach 1945-1961” był teэW matem rozprawy doktorskiej Witolda Bagieńskiego obronionej w 2014 roku w Instytucie Historii Polski Akademii Nauk. Na rynku wydawniczym od niespełna roku (chociaż jako data wydania figuruje rok 2017) funkcjonuje monografia pod tym samym tytułem, będąca - jak podaje Autor - rozszerzeniem pracy doktorskiej i stanowiąca wynik wieloletnich, badań nad dokumentacją wytworzoną przez służby specjalne państwa polskiego w pierwszych 15 latach po zakończeniu drugiej wojny świato-
\end{abstract}


wej. Autor jest pracownikiem naukowym Instytutu Pamięci Narodowej (IPN): Samodzielnej Sekcji Badań Archiwalnych i Edycji Źródeł Biura Udostępniania i Archiwizacji Dokumentacji. Jego wcześniejszy opublikowany dorobek naukowy obejmuje współudział w trzech większych opracowaniach zbiorowych, w tym dwóch edycjach źródłowych oraz kilka artykułów i recenzji ${ }^{1}$. Omawiana publikacja jest pierwszym, większym, samodzielnym opracowaniem Autora. Daje czytelnikom oraz badaczom najnowszych dziejów Polski zwarty i interesujący wykład oparty o solidną podstawę źródłową, który wypełnia lukę w istniejącej historiografii tej epoki.

Użyta w tytule pracy nazwa państwa „Polska Ludowa” może budzić wątpliwości, gdyż oficjalna nazwa do 1952 roku brzmiała „Rzeczpospolita Polska”, a po ogłoszeniu nowej konstytucji „Polska Rzeczpospolita Ludowa”. Zakres chronologiczny publikacji W. Bagieńskiego nakłada się na oba te okresy, stąd przypuszczalnie próba obejścia obu nazw i zastąpienie nazwą potoczną i używaną propagandowo przez władze, która jednakże dość mocno zakorzeniła się w codziennym użyciu, także i współcześnie. Widać to m.in. w wielu publikacjach IPN, który z jednej strony mocno odcina się od minionego czasu, a z drugiej, bezkrytycznie propaguje ówczesną nomenklaturę, np. w nazwie serii wydawniczej „Aparat Represji w Polsce Ludowej”. Wielu autorów, także pracowników IPN, by pozostawać w zgodzie z faktyczną terminologią, używa nazwy ogólnej i ponadczasowej: „Polska”2, „państwo polskie”3 lub innej ${ }^{4}$. Recenzent rozprawy doktorskiej prof. Włodzimierz Suleja zauważył, iż:

${ }^{1}$ M.in.: Stanistaw Mikotajczyk w dokumentach aparatu bezpieczeństwa, t. 1: Dziatalność w latach 1945-1947, wstęp J. Gmitruk, wybór dokumentów W. Bagieński, F. Dąbrowski, F. Gryciuk, oprac. W. Bagieński, P. Byszewski, A. Chrzanowska, F. Dąbrowski, F. Gryciuk, J. Mysiakowska-Muszyńska, Warszawa 2010; Afera Żelazo w dokumentach MSW i PZPR, wybór, wstęp i oprac. W. Bagieński, P. Gontarczyk, Warszawa 2013; S. Cenckiewicz, W. Bagieński, P.Woyciechowski, Konfidenci. Archiwa ujawniaja prawdę, Warszawa 2015.

${ }^{2}$ Np. Aparat bezpieczeństwa w Polsce. Kadra kierownicza, t. 1: 1945-1956, red. K. Szwagrzyk, Warszawa 2005; M. Golon, Radzieckie stużby dyplomatyczne i konsularne w Polsce w latach 1944-1961, „Czasy Nowożytne” 2007, 2-7, nr 20, s. 165-251.

${ }^{3}$ Np. W. Roszkowski, Historia Polski 1914-2005, Warszawa 2007 i inne wydania.

${ }^{4}$ A. Paczkowski, Wywiad cywilny Polski komunistycznej 1945-1989. Próba ogólnego zarysu, „Zeszyty Historyczne” 2005, z. 152, s. 3-25. 
Purysta mógłby mieć wprawdzie zastrzeżenia do sformułowania samego tytułu (okres 1945-1961 obejmuje wszak, precyzyjnie rzecz ujmując, czas Polski Ludowej i od roku 1952 PRL), ale nie ma to przecież wpływu ani na tok wywodu, ani tym bardziej na jego udokumentowanies.

Warto nadmienić, że recenzent użył także nazwy forsowanej propagandowo „Polska Ludowa” zamiast poprawnej „Rzeczpospolita Polska”. Autor recenzji zamieszczonej w „Rzeczpospolitej”, prof. Krzysztof Tarka, nie uznał za potrzebne odniesienie się do tej kwestii ${ }^{7}$. Jednak autor omawianej publikacji w stosowanej terminologii nie jest odosobniony, można przytoczyć przykłady używania nazwy „Polska Ludowa” w tytułach i treści prac naukowych ${ }^{8}$, zatem trudno uznać to za fundamentalny błąd, chociaż może warto używać cudzysłowu9. Natomiast należy zauważyć, że sam Autor w ogóle nie dostrzegł tego problemu, ani pisząc autoreferat na potrzeby obrony pracy doktorskiej ${ }^{10}$, ani we wstępie do omawianej publikacji, w których - zgodnie z wymaganiami metodycznymi - powinien wyjaśnić wszelkie problemy występujące w związku z użyciem w tytule określonych pojęć, tymczasem skupił się na wyjaśnieniach dotyczących jedynie definicji wywiadu cywilnego.

5 Recenzja rozprawy doktorskiej mgr. Witolda Bagieńskiego Wywiad cywilny Polski Ludowej $w$ latach 1945-1961, s. 2, https://ihpan.edu.pl/wp-content/.../Recenzja-prof.dr.-hab.-Włodzimierza-Sulei.pdf [dostęp 11.02.2018 r.]

${ }^{6}$ Podobnie zrobił np. A. Paczkowski: Razem czy osobno: próba „organicznego potaczenia” wywiadów Polski Ludowej w latach 1947-1950, „Dzieje Najnowsze” 2015, nr 4, s. 119-146.

7 K. Tarka, Witold Bagieński. Jak rodzit się wywiad cywilny w Polsce Ludowej, https:// www.rp.pl/Plus-Minus/305049980-Witold-Bagienski-Jak-rodzil-sie-wywiad-cywilny-wPolsce-Ludowej.html [dostęp 11.02.2018 r.]

${ }^{8}$ Np. Polska Ludowa 1980-1989, red. P. Dybicz, cz. 1, Warszawa 2015, cz. 2, Warszawa 2016.

${ }^{9}$ Np. A. Dziurak, M. Gałęzowski, Ł. Kamiński, F. Musiał, Od niepodlegtości do niepodlegtości. Historia Polski 1918-1989, Warszawa 2010, s. 206-210;Ogólnopolska Konferencja Naukowa „Polska Ludowa” 1944-1989: geneza, stabilizacja, kryzys, upadek. Abstrakty, red. K. Bałękowski, K. Maciąg, Lublin 2016; G. Tokarz, Polska Ludowa w polskiej myśli politycznej (1989-2004), Warszawa 2013.

${ }_{10}$ W. Bagieński, Wywiad cywilny Polski Ludowej w latach 1945-1961, „Dzieje Najnowsze” 2015, nr 1, s. 191-201. 
Witold Bagieński swoją monografię podzielił na dwa tomy. Uważam ten podział za zasadny, wynikający zapewne z objętości całości. Pierwszy tom liczy 640 stron i obejmuje dwie odrębne części, natomiast część trzecia mieści się w drugim tomie obejmującym 696 stron. Tomy, oprócz części, podzielono na rozdziały i podrozdziały. W tomie drugim zamieszczono osiem aneksów zawierających szczegółowe tabele przedstawiające strukturę wywiadu cywilnego, jego finanse i kilka imiennych wykazów, w tym kadry kierowniczej. Sumy obrazujące finanse wywiadu byłyby bardziej czytelne, gdyby Autor odniósł się do siły nabywczej ówczesnej polskiej waluty, czy średniej wysokości zarobków. Dołączono tu również, niezbędny w tej publikacji, wykaz skrótów. W tomie drugim znajduje się również obszerna bibliografia, spis ilustracji i tabel, a także - rzadko spotykane w publikacjach, a w tej wręcz pożądane - indeksy: nazw geograficznych, pseudonimów oraz kryptonimów. Każdy czytelnik będzie wdzięczny Autorowi za podjęcie się trudu ich wykonania, nie mówiąc, że podnosi to walory informacyjne publikacji.

Cezurę początkową - rok 1945 - stanowi moment utworzenia wywiadu cywilnego czyli Wydziału Wywiadu w strukturze Ministerstwa Bezpieczeństwa Publicznego (MBP) i jest ona bezdyskusyjna. Z kolei cezurę końcową- rok 1961 - Autor wybrał z uwagi na znaczne zmiany w wewnętrznej organizacji wywiadu cywilnego dokonanej na skutek ucieczek funkcjonariuszy Departamentu I MSW, ppłk. Michała Goleniewskiego i kpt. Władysława Mroza, uznając, że po tych wydarzeniach służba nie była w stanie długo podnieść się z głębokiego kryzysu. Nie do końca wydaje się to przekonujące, może należałoby zakończyć na październiku 1956 roku (kiedy powołano Ministerstwo Spraw Wewnętrznych) lub konsekwentnie opisać całość do roku 1990 (kiedy zlikwidowano Departament I MSW), jakkolwiek wydaje się to monumentalnym przedsięwzięciem.

Konstrukcja monografii jest przemyślana i logiczna, ale wbrew deklaracjom Autora (cz. I, s. 15), trzy części opracowania nie mają układu chronologiczno-problemowego (cz. I: „Zmiany organizacyjno-strukturalne i uwarunkowania pracy wywiadu”, cz. II: „Infrastruktura wywiadowcza”, cz. III: „Wybrane aspekty działalności wywiadu”), ale problemowy. Również układ poszczególnych rozdziałów jedynie w części pierwszej został oparty o chronologię, w dwóch pozostałych jest zdecydowanie problemowy. 
W części pierwszej, podzielonej na pięć rozdziałów, W. Bagieński omawia zmiany organizacyjno-strukturalne i funkcjonowanie komórek organizacyjnych wywiadu cywilnego w MBP oraz Komitecie ds. Bezpieczeństwa Publicznego przy Radzie Ministrów (KdsBP) i Ministerstwie Spraw Wewnętrznych. Chronologiczny układ rozdziałów pozwala Autorowi po kolei i dość czytelnie odsłaniać różnorodne fakty i wydarzenia, które rozpoczyna opis genezy i okoliczności powołania struktur organizacyjnych Wydziału Wywiadu MBP, następnie dobór kadry kierowniczej i jej specyfikę. Wywiad cywilny w Polsce powojennej od początku swego istnienia był ważnym elementem w strukturze organów bezpieczeństwa państwa i wykonywał szeroko zakrojoną pracę operacyjną w zakresie kontrolowania społeczeństwa i zwalczania tzw. wroga wewnętrznego. Jednym z celów badawczych, jakie przed sobą postawił W. Bagieński, była próba odtworzenia „mechanizmów nadzoru i kontroli nad aparatem represji Polski Ludowej ze strony służb sowieckich”, co z uwagi „obowiązującą w ZSRR zasadę niepozostawiania śladów niektórych działań w oficjalnej dokumentacji” (cz. I, s.10), nie udało się do końca, aczkolwiek Autor dość obszernie ukazał działalność sowieckich doradców w MBP. Krytycznie pisze o całości kadry wywiadu cywilnego, jej niskim poziomie intelektualnym, pijaństwie, braku dyscypliny, popełnianych wykroczeniach służbowych i kryminalnych (cz. I, s. 69-73). Autor zwraca uwagę na fakt, że wywiad pracował pod bezpośrednim nadzorem sowieckiego wywiadu, a więc nie był „wywiadem cywilnym polskim”, gdyż jego struktury, kadra oficerska, kierunki działań były pochodną służb sowieckich. Pod nadzorem sowieckiego wywiadu cywilnego Pierwszego Zarządu Głównego Ludowego Komisariatu Bezpieczeństwa Państwowego ZSRS i w oparciu o jego wzorce organizacyjne budowano Wydział Wywiadu MBP, wykorzystywano sowieckie metody pracy i terminologię fachową (cz. I, s. 32-33). Jednakże wiele osób funkcyjnych, jakkolwiek wielu miało w biografii pobyt w Związku Sowieckim, to urodzeni w przedwojennej Rzeczypospolitej obywatele polscy, komuniści, bądź związani z NKWD, bądź przeszkoleni na kursach wywiadowczo-dywersyjnych w Szkole Kominternu, bądź działacze Związku Patriotów Polskich.

Do spraw kadry Autor wraca w rozdziale drugim („Połączenie wywiadu cywilnego z wywiadem wojskowym lipiec 1947-czerwiec 1950", s. 127-143), gdzie stawia tezę, że „podobnie, jak w latach 1945-1947 zde- 
cydowana większość kadry kierowniczej i spory procent pozostałych pracowników Departamentu VII było pochodzenia żydowskiego" (s. 130). Powołuje się na głównie literaturę przedmiotu, ale również na nieliczne dokumenty, jakkolwiek ten wątek zasługuje na szersze potraktowanie. Wydaje się, że kwestie kadr kierowniczych i pracowników wywiadu cywilnego dominują we wszystkich rozdziałach (chociaż tylko w drugim poświęcono im odrębny podrozdział), co zrozumiałe, gdy to oni kreowali opisywaną rzeczywistość, ale czy nie warto byłoby ich charakterystyce poświęcić odrębny rozdział? Np. w rozdziale trzecim znalazły się interesujące analizy „życia zawodowego i partyjnego" funkcjonariuszy wywiadu, życia osobistego, rozrywek i spraw dyscypliny. Ciekawe są spostrzeżenia Autora odnoszące się do sprawy zatrudniania kobiet w wywiadzie, aczkolwiek są one marginalne - chyba nie tylko z racji, że było ich niewiele, ale również dlatego, że ich rola z upływem lat malała i służyły prawie wyłącznie w pionach biurowych.

Interesujące dla czytelnika jest przedstawienie różnych spraw operacyjnych prowadzonych przez wywiad cywilny ze wskazaniem na sukcesy i porażki, w tym najbardziej znanej, sprawę Józefa Światły, która wywołała reorganizację i likwidację MBP. Sprawa Światły jest jedną z bardziej znanych porażek polskich służb, wielokrotnie opisywaną, ale Autorowi udało się uzupełnić jej opis o nowe informacje w oparciu o odnalezione pisma i raporty (s. 243-247). Autor skupił wiele uwagi wokół metod działania i pracy operacyjnej wywiadu, a szczególnie werbunku współpracowników. Rozrzucenie informacji na ten temat w różnych miejscach nie pozwala jednak do końca skupić się na problemie.

W drugiej części publikacji zatytułowanej „Infrastruktura wywiadowcza” Autor przedstawił organizację i tworzenie siatek wywiadowczych oraz rezydentur za granicą w latach czterdziestych i początkach lat pięćdziesiątych, ich funkcjonowanie oraz metody pracy funkcjonariuszy zatrudnionych w tych placówkach. Znacznie mniej miejsca Autor poświęcił krajowym jednostkom pomocniczym wywiadu: sekcji II specjalnej, placówkom oficerskich i samodzielnym grupom specjalnym a także pionowi informacyjnemu wywiadu w latach czterdziestych i pierwszej połowie lat pięćdziesiątych. Ta nieproporcjonalna w stosunku do innych rozdziałów objętość, wynika prawdopodobnie z braku zachowanych dokumentów i krótkiego okresu istnienia w tej formie. W kolejnym rozdziale Autor przedstawia 
ośrodki szkoleniowe dla przyszłych pracowników wywiadu (szkoły: oficerską techniczną, wywiadowczą, agentów, kontrwywiadowczą i inne) oraz specjalistyczne kursy, ze wskazaniem okresu ich funkcjonowania. Tu omówił również procedurę werbunkową kandydatów do pracy w MBP/MSW.

Najbardziej interesująca, ponieważ ukazująca różne mało znane oblicza wywiadu cywilnego, część trzecia omawianej publikacji składa się aż z sześciu rozdziałów pod ogólnym tytułem „Wybrane aspekty działalności wywiadu". Każdy ukazany tu problem stanowi samodzielny problem badaczy zasługujący na odrębne opracowania. Dosyć obszernie Autor opisał walkę wywiadowczą z polską emigracją polityczną w pierwszych latach po wojnie, po październiku 1956 roku i zakończył na początku lat sześćdziesiątych - prawdopodobnie, aby pozostać w zgodzie z ramami chronologicznymi swojego opracowania. Podobnie został potraktowany kolejny temat o walce z obcymi ośrodkami wywiadowczymi, polską emigracją wojskową i zachodnimi służbami specjalnymi, który obejmuje jedynie lata czterdzieste i pięćdziesiąte. W kolejnym rozdziale została omówiona kontrwywiadowcza „ochrona” placówek dyplomatycznych przed i po 1956 roku, relacje między wywiadem MBP a resortem spraw zagranicznych, w tym szczególnie rola wywiadu w „oczyszczaniu” kadry MSZ. Autor sięgnął w celach weryfikacyjno-porównawczych do archiwaliów MSZ. Wywnioskował, że ciągle powtarzające się „czystki” doprowadzały do zahamowania działalności wywiadu, w którego obszarze zainteresowania było m.in. pozyskiwanie informacji potrzebnych do rozwoju przemysłu elektronicznego i militarnego. Autor podkreśla to zauważając paradoksalnie, że „oczyszczanie placówek z osób niepewnych politycznie uznawano za podstawowy warunek umożliwiający prowadzenie skutecznej działalności wywiadowczej” (cz. I, s. 13). Rozdział czwarty traktuje o początkach wywiadu naukowo-technicznego i utworzeniu pionu naukowo-technicznego w wywiadzie cywilnym przed i po 1956 roku oraz osiągnięciach tegoż wywiadu. Autor postawił tezę, że to ówczesna sytuacja polityczna zmuszała do podejmowania ryzyka pozyskiwania technologii w sposób specjalny, poprzez wywiad. Szkoda, że mimo iż do tej pory te sprawy nie były przedmiotem badań naukowych, zostały przez Autora jedynie zasygnalizowane. Niektóre, wcześniej omawiane, zagadnienia zostały powtórzone lub poszerzone, jak np. ucieczka ppłk. Michała Goleniewskiego i jej skutki (cz. I, r. 1). Rozdział piąty przedstawia 
genezę i teorię pracy tzw. wywiadu nielegalnego w Polsce Ludowej, w tym także sytuację w okresie po połączeniu wywiadów. To również „biała plama” na mapie polskich badań naukowych, którą udało się W. Bagieńskiemu dość syntetycznie pokazać, aczkolwiek należy zapytać, czy to wszystko, co na ten temat można napisać, czy dopiero dobrze zaczęty, etap wstępny. W ostatnim rozdziale Autor wskazuje źródła pozyskiwania pozabudżetowych środków finansowych przez wywiad, który, aby stać się „samowystarczalny”, próbował w krajach Zachodu zdobywać środki finansowe na swoją działalność. Omawia genezę Specjalnej Sekcji Finansowej i jej złoty okres: działalność „zarobkową” wywiadu do początku lat sześćdziesiątych, handel złotem i dewizami przez rezydenturę w Tel Awiwie i kurierów dyplomatycznych, a następnie likwidację.

$\mathrm{Na}$ uznanie zasługuje obszerna bibliografia podzielona na działy: archiwa, akty prawne i dzienniki urzędowe, opracowania wewnętrzne MBP/ KdsBP/MSW, źródła drukowane, wspomnienia, relacje, wywiady, opracowania, monografie i zbiory studiów, artykuły, prasa, informatory i słowniki, źródła internetowe (s. 574-605). Zwraca tu uwagę bogata baza źródłowa obejmująca głównie materiały z archiwów IPN - zarówno centrali w Warszawie, jak w nieporównanie mniejszym zakresie - oddziałów terenowych, ale również m.in. Archiwum Ministerstwa Spraw Zagranicznych, Archiwum Akt Nowych, Centralne Archiwum Wojskowe i zbiory polskie zagranicą. Warto podkreślić świadomość Autora, który podczas pisania nie mógł skorzystać z tzw. Zbioru Zastrzeżonego IPN ${ }^{11}$ i zdaje sobie sprawę, że jego ujawnienie może wpłynąć na potrzebę weryfikacji lub uzupełnienia ustaleń poczynionych w publikacji. Choć W. Bagieński podkreśla, że „w odróżnieniu od wielu innych jednostek UB/SB, w wypadku wywiadu brakuje zupełnie podstawowej dokumentacji” (s.17), to udało mu się z dobrym skutkiem wykorzystać tę, która się zachowała.

Warto zwrócić uwagę na ciekawą stronę graficzną publikacji. Wiele fotografii, schematów i kopii dokumentów przerywa naukową narrację, którą tu potraktowano podręcznikowo. W każdym tomie zamieszczono biogramy najważniejszych, według Autora, osób wymienionych w publikacji wraz z fotografią oraz podaniem podstawy źródłowej. Ten wysiłek

${ }^{11}$ Formalnie został zlikwidowany w połowie 2017 r. 
badawczy należy szczególnie docenić, tym bardziej, że są to często osoby mało znane. Ukazując, kim byli ludzie, którzy kierowali wywiadem cywilnym, Autorowi udało się w sposób przejrzysty, przedstawić charakterystyki funkcjonariuszy piastujących kluczowe stanowiska. Przy tak dużej liczbie biogramów przydałby się alfabetyczny spis nazwisk, które „giną” w indeksie osobowym (mimo pogrubienia numeru strony, na której ów biogram się znajduje), albo wykonanie na ich podstawie słownika biograficznego jako załącznika do całości.

W. Bagieński wielokrotnie sięga do oryginalnych dokumentów, nie tylko w przypisach, ale przywołując dosłownie ich treść w tekście, co sprawia, że czytelnik może odnieść wrażenie, że Autor woli, aby zamiast interpretacji, przemówiło źródło. Jest to niewątpliwie urozmaicenie treści. Można jednak odnieść wrażenie, że Piszący zanadto ulega magii dokumentów wytworzonych przez opisywane służby $i$ inne, powiązane z nimi, a narracja w wielu miejscach powstała jako skutek opisywania/cytowania treści służbowych pism, analiz, opinii i innej korespondencji. Język całości wywodu jest łatwy w odbiorze nawet dla niezbyt dobrze zorientowanego w temacie czytelnika, który bez problemu zrozumie tekst i odnajdzie się w gąszczu zawodowego żargonu używanego w służbach specjalnych. Atutem monografii jest podanie definicji specjalnych pojęć w tekście głównym i przypisach rzeczowych, chociaż bardziej przydatny mógłby okazać się alfabetyczny słownik pojęć, w którym łatwiej byłoby je wyszukać. Jednak czytając niektóre tytuły podrozdziałów, można odnieść wrażenie, że to doniesienie prasowe o charakterze niemalże sensacyjnym, (np. r. I. 2: Początek czarnej passy). Rażące z punktu widzenia pracy naukowej jest uprzedzanie w tytułach, jakie są wyniki przeprowadzonych badań, wnioski i oceny wynikające $\mathrm{z}$ analizy materiału (zdradzanie czytelnikowi zakończenia nie jest najlepszym zabiegiem), pomijając już niezręczności językowe (np. r. I. 2: Ściślejsze połączenie wywiadów, Ostateczne załamanie w działalności operacyjnej, Zdradziecka działalność Stanisława Kühnera; r. I. 3: Nieudana reorganizacja, r. I. 5: Czystka i zła atmosfera w wywiadzie; III. 3: Zmiana charakteru działania pionu kontrwywiadowczego).

Wiele ustaleń Witolda Bagieńskiego ma charakter nowatorski, czemu niewątpliwie posłużyło oparcie badań na niewykorzystywanych (z braku możliwości i warunków) wcześniej przez badaczy archiwaliach, które 
poddał wnikliwej analizie. Autor odkrył dla czytelników i badaczy wiele ciekawych, i zarazem nieznanych faktów, osób i wydarzeń. Ważne wydają się ustalenia w kwestiach poprawnych nazw komórek organizacyjnych zajmujących się wywiadem cywilnym. Prezentowana monografia to obszerne kompendium wiedzy na temat wywiadu cywilnego w pierwszych latach powojennej Polski, które mimo - niewątpliwie dyskusyjnych - uwag, ma już swoje miejsce w dorobku historiografii nad powojennymi dziejami Polski.

Renata Maria Żegunia (Toruń) ORCID: 0000000314282662 